\title{
STRUCTURAL INDEXES AND SEXUAL MATURITY OF TAMBAQUI COLOSSOMA MACROPOMUM (CUVIER, 1818) (CHARACIFORMES: CHARACIDAE) IN CENTRAL AMAZON, BRAZIL
}

\author{
VILLACORTA-CORREA, M. A. ${ }^{1}$ and SAINT-PAUL, U. ${ }^{2}$ \\ ${ }^{1}$ Instituto Nacional de Pesquisas da Amazônia (INPA), Coordenação de Pesquisas em Aqüicultura (CPAQ), \\ Alameda Cosme Ferreira, 1756, C.P. 478, CEP 69011-970, Manaus, Amazonas, Brazil \\ ${ }^{2}$ Center for Tropical Marine Ecology, Fahrenheitstr, 1D-28359 Bremen, Germany \\ Correspondence to: Marle Angélica V. Correa, Instituto Nacional de Pesquisas da Amazônia (INPA), \\ Coordenação de Pesquisas em Aqüicultura (CPAQ), Alameda Cosme Ferreira, 1756, C.P. 478, \\ CEP 69011-970, Manaus, Amazonas, Brazil, e-mail: marle@inpa.gov.br \\ Received October 21, 1998 - Accepted January 18, 1999 - Distributed December 22, 1999
}

(With 13 figures)

\begin{abstract}
Length, weight, structural index and sexual maturity in tambaqui Colossoma macropomum were analysed. 449 specimens were obtained from the commercial fishing fleet arriving at Manaus Harbour from the floodplain areas from May 1992 to July 1993. The objective of this study is to describe changes in structural index during one hidrological cycle and to interpret them according to the water level fluctuations and to also determine the time, reproductive period and length in sexual maturity. Sex ratio in tambaqui was 1:1 however, the length of females was significantly longer than males'. Length/weight relationship was described by the expression: $\mathrm{Pt}=0.00058^{*} \mathrm{Cp}^{2.9039}$. $\mathrm{b}$ value was significantly different from 3 which meant an alometric growth. Lower condition index values (Kn) were found from August to October at the end of receding water and dry period. The feeding index was significantly lower during the receding water and dry period. Lower hepatosomatic index values were found in December during the dry period. Fishes in lengths longer than $550 \mathrm{~mm}$ which were more common from September to December during the dry period, stored larger cavitary fat reserves. Fishes smaller than the standard length of $550 \mathrm{~mm}$ stored less fat reserves and were more common during the rising of the water and flooding period. Spawning period of tambaqui extends from September to February in a total spawning synchronized with "repiquetes" (native term used to name a sudden recending and rising of the water level). Length of tambaqui was $60.69 \mathrm{~cm}$, at sexual maturity.
\end{abstract}

Key words: Colossoma macropomum, floodplains, structural index, reproduction, sexual maturity.

\section{RESUMO}

\section{Índices estruturais e maturidade sexual do tambaqui Colossoma macropomum (Cuvier, 1818) (Characiformes: Characidae) no Amazonas Central, Brasil}

Foi analisada a relação peso comprimento, os índices estruturais e a maturidade sexual do tambaqui Colossoma macropomum. Foram obtidos 449 exemplares procedentes das áreas de várzea do Amazonas Central no porto de desembarque de Manaus de maio de 1992 a julho de 1993. O objetivo deste trabalho foi descrever as modificações nos índices estruturais do tambaqui durante um ciclo hidrológico, interpretá-los de acordo com as flutuações do nível da água e determinar a época, período de reprodução e comprimento da maturidade sexual. A proporção entre sexos no tambaqui é de 1:1, porém os comprimentos das fêmeas foram significativamente superiores aos dos machos. A relação peso comprimento é descrita pela expressão $\mathrm{Pt}=0,00058^{*} \mathrm{Cp}^{2,9039}$. O valor de b foi significativamente diferente de 3 , que significa um crescimento alométrico. Os valores mais baixos do índice de condição $(\mathrm{Kn})$ foram 
encontrados de agosto a outubro no fim da vazante e seca. O índice alimentar foi significativamente mais baixo durante a vazante e seca. Menores valores do índice hepatossomático foram encontrados em dezembro durante a seca. Os peixes acumularam maiores reservas de gordura cavitária nos comprimentos maiores a $550 \mathrm{~mm}$, os quais foram mais freqüentes de setembro a dezembro durante a seca. Peixes menores de $550 \mathrm{~mm}$ de comprimento-padrão acumularam menos reservas de gordura e foram mais frequientes durante a enchente e cheia. O período de desova do tambaqui se estende de setembro a fevereiro em uma desova total sincrônica com os "repiquetes". O comprimento da maturidade sexual do tambaqui foi de $60,69 \mathrm{~cm}$.

Palavras-chave: Colossoma macropomum várzeas, índices estruturais, reprodução, maturidade sexual.

\section{INTRODUCTION}

The understanding of species' biology and life cycle is a major factor for the establishment of suitable policies regarding fishery regulations as well as for its farming viability. Tambaqui Colossoma macropomum (Fig. 1) among all other fish species within central amazonian fisheries, stands out for its higher commercial value and consumer's preference. When studying landing data according to model of production, Merona \& Bittencourt (1988), pointed this species out as being in an over exploited situation.
Tambaqui is one of the best studied amazonian species both regarding its captivity production (Saint-paul, 1986, 1990) autoecology and life cycle (Honda, 1974; Goulding, 1980, 1981; Goulding \& Carvalho, 1982). However, some aspects of its biology are not fully cleared.

Mean length of sexual maturity is a very important population parameter for rational stock management, because it serves to set the shortest length for capture and to determine the net mesh size. Time and duration of reproductive period also constitute two critical components in a organism's life strategy.

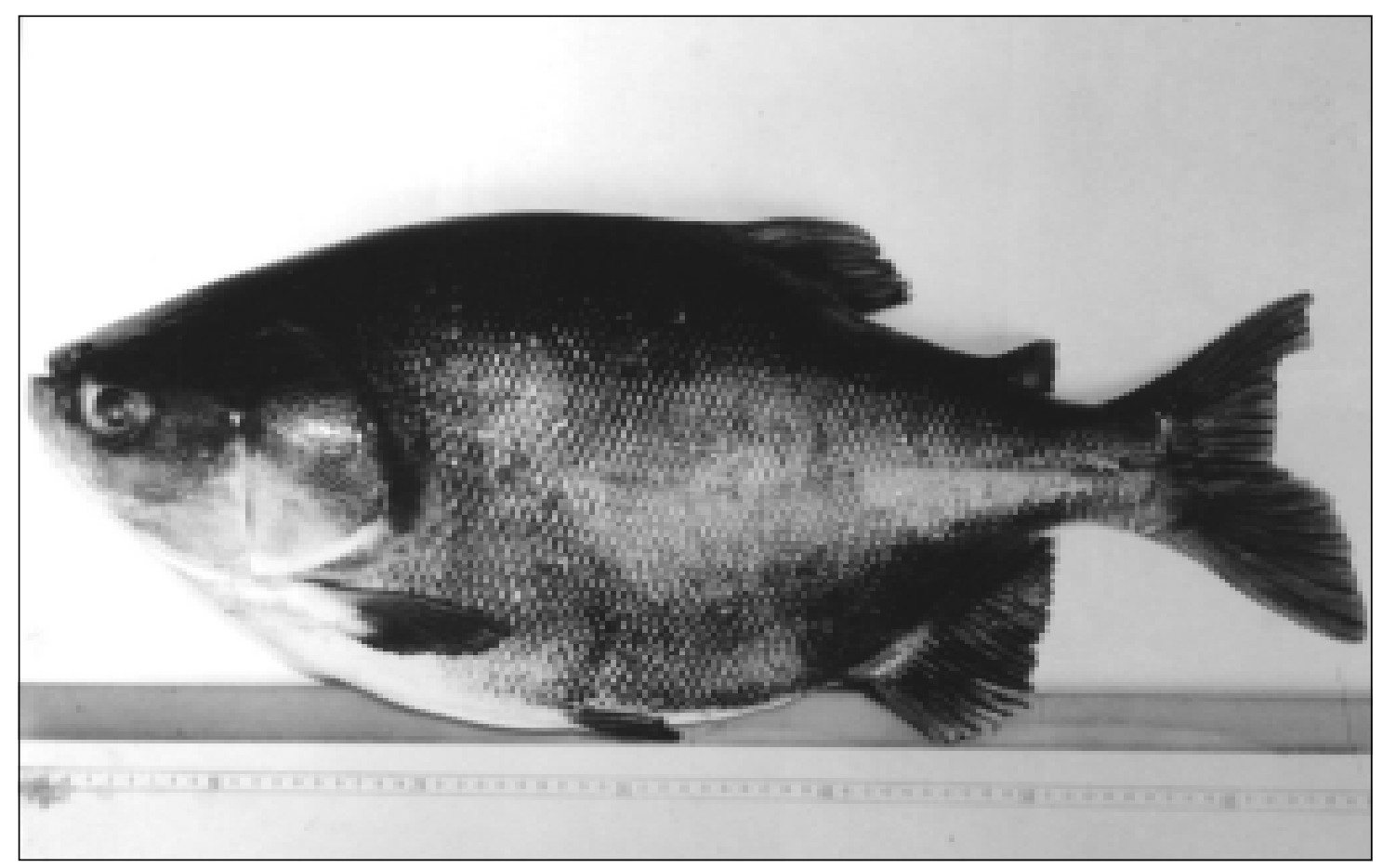

Fig. 1 - Specimen of tambaqui C. macropomum. 
These parameters are necessary to subsidize the resources' administration polices, management, and preservation when facing environmental impacts (Vazzoler, 1996).

Fishing tambaqui in Amazonas State is subjected to some policies, such as; 1) prohibition of capture during reproduction period "periodo de defeso" (late December early March) and 2) shortest length for capture of $55 \mathrm{~cm}$. Despite these policies, the actual knowledge about the species' reproductive process (reproduction timing and sexual maturity size) are not enough to support a proper fishing policy. There is only one work in Central Amazonas (Pinheiro, 1985), whose results were not published, concerning first maturity and spawning time.

Condition index $(\mathrm{Kn})$ determines the period in which fish builds up more biomass within its body and enables to determine seasonal changes in the physiological condition relating to age, sex, and different habitats (Le Cren, 1951). Gonadosomatic index (GSI) describes the species' reproductive condition, through changes in the relative gonad size in relation to time. Hepatosomatic index (HSI) is important because it describes the fish's stored energy.

Tambaqui's structural indexes, sexual maturity length and spawning period are analysed in this paper. Results are simultaneously interpreted according to the hydrological cycle fluctuations.

\section{MATERIAL AND METHODS}

The analysed material was obtained from the Manaus commercial fishing fleet landings and from experimental fisheries in floodplain areas near Manaus, from May 1992 to July 1993. The collected material was from Rio Solimões and affluents, bordered by Rivers Japura, Purus, Juruá and Madeira (Fig. 2; Table 1).

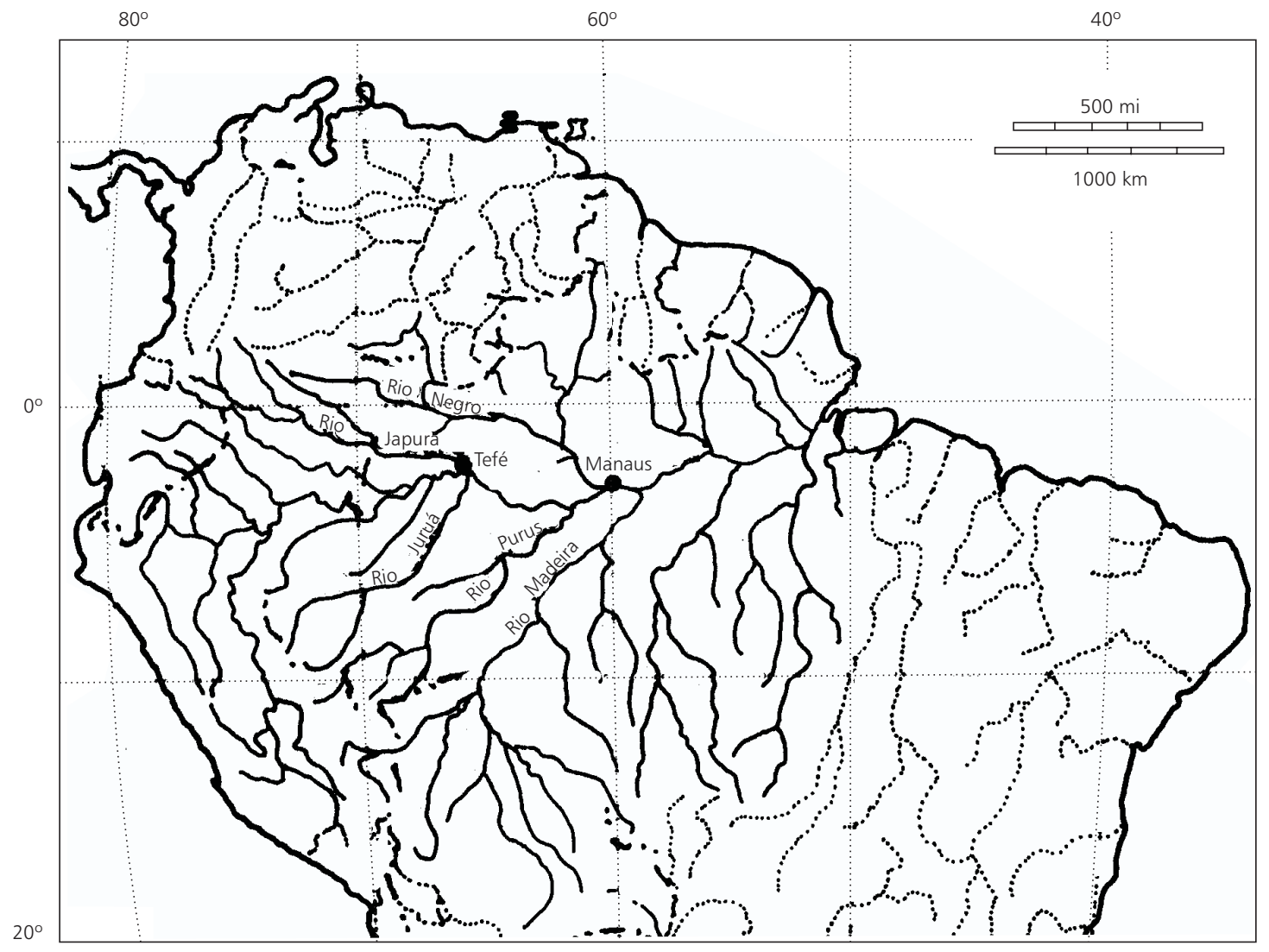

Fig. 2 - Source of C. macropomum specimens. 
TABLE 1

Locality, date and number of specimens (n) of $C$. macropomum throughout the period of study. ND = nondetermined locality.

\begin{tabular}{|c|c|c|c|}
\hline Locality & River & Date & $\mathbf{n}$ \\
\hline Lago Janauacá & Solimões & $04-05-92$ & 41 \\
\hline Lago dos Reis & Solimões & 01-06-92 & 31 \\
\hline ND & Solimões & $01-07-92$ & 25 \\
\hline ND & Purus & $07-08-92$ & 20 \\
\hline Paraná do Ramo & Solimões & $14-09-92$ & 20 \\
\hline Atí Paraná & Solimões & $15-09-92$ & 01 \\
\hline ND & Japurá & $13-10-92$ & 25 \\
\hline Novo Airão & Negro & $14-11-92$ & 19 \\
\hline ND & Purus & $15-11-92$ & 10 \\
\hline ND & Purus & $12-12-92$ & 13 \\
\hline Lago Janauacá & Solimões & $30-01-93$ & 09 \\
\hline Manacapurú & Solimões & $24-01-93$ & 01 \\
\hline Careiro & Solimões & $24-01-93$ & 02 \\
\hline Terra Nova & Solimões & $24-01-93$ & 01 \\
\hline Coari & Solimões & $24-01-93$ & 18 \\
\hline Manacapurú & Solimões & $28-02-93$ & 07 \\
\hline ND & Juruá & $20-03-93$ & 04 \\
\hline Lago Jarí & Purus & $20-03-93$ & 08 \\
\hline Coarí & Solimões & $09-02-93$ & 04 \\
\hline Ilha de Marchantaria & Solimões & $17-02-93$ & 03 \\
\hline Lago Puraquequara & Solimões & $19-02-93$ & 03 \\
\hline Lago Janauacá & Solimões & $22-03-93$ & 48 \\
\hline ND & Solimões & $21-03-93$ & 13 \\
\hline Lago Janauacá & Solimões & 02-04-93 & 15 \\
\hline Lago Janauacá & Solimões & $14-04-93$ & 24 \\
\hline ND & Solimões & 07-04-93 & 09 \\
\hline Lago Janauacá & Solimões & $14-04-93$ & 04 \\
\hline ND & Solimões & $18-04-93$ & 18 \\
\hline Lago Janauacá & Solimões & $27-04-93$ & 14 \\
\hline Autazes & Madeira & $10-05-93$ & 08 \\
\hline ND & Negro & $21-05-93$ & 01 \\
\hline Coarí & Solimões & $15-05-93$ & 09 \\
\hline Manacapurú & Solimões & $13-05-93$ & 12 \\
\hline Careiro & Solimões & $15-05-93$ & 04 \\
\hline ND & Solimões & $05-06-93$ & 02 \\
\hline ND & Juruá & $02-07-93$ & 03 \\
\hline TOTAL & & & 449 \\
\hline
\end{tabular}


The following data were recorded: total length, fork length and standard length $(\mathrm{mm})$, total weight and gutted weight (g), sex, sexual maturity, cavitary fat accumulation, weight of gonads, weight of stomach, weight of stomachal content and weight of liver.

The sex of fish was identified through macroscopical observation of gonads and the sexual maturity status by using scale from I to $\mathrm{V}$, taken the one described by Nikolsky (1963) as a basis. "undetermined" was the term used when it was impossible to distinguish the sex due to the early formation of sexual organs "non determined" was used when the material's state of conservation wouldn't allow sex identification, or if there were any doubts.

Aiming to facilitate comparison of results in this work with those in literature, regressions between length measurements (whole length/fork length/standard length and vice-versa) and between weights (total and gutted) were undertaken.

Sex ratio was tested through chi square test applied to male and female absolute frequencies by standard length group. And t test was applied for differences between males and females mean lengths (Sokal \& Rolf, 1995).

To know whether value of $b$ is significantly different from 3 t test (Pauly, 1984), was applied separately for each sex.

Condition factor $(\mathrm{Kn})$, hepatosomatic index (HSI), feeding index (FI), and gonadosomatic index (GSI) were estimated according to the following expressions: $\mathrm{Kn}=$ Gutted weight $/ \mathrm{aCp}^{\mathrm{b}}$; HSI $=$ Liver weight $/ \mathrm{aCp}^{\mathrm{b}} ; \mathrm{FI}=$ Stomach content weight $/ \mathrm{aCp}^{\mathrm{b}} \mathrm{x}$ 100; GSI = Gonad weight $\mathrm{aCp}^{\mathrm{b}} \times 100$ (Anderson \& Neumann, 1996). Where: $\mathrm{aCp}^{\mathrm{b}}$ is the fish's estimated weight.

These indexes were estimated for all individual. To calculate estimated weight $\left(\mathrm{aCp}^{\mathrm{b}}\right)$, a and b Length/weight relationship values were taken for each sex separately.

Gutted weight was used for eliminating any influence on the inner organ' weight due to seasonal changes in the fish weight (Sayer et al., 1995). One way ANOVA was applied in order to determine whether there were any significantly statistical differences between the months sampled and a less significant differences test (LSD) in order to determine the differences between every index's monthly mean. Spawning period was determined according to GSI variation and by individual monthly frequencies in each sexual maturity stage. Male and female samples were grouped in $2 \mathrm{~cm}$ standard length classes and mature individual frequencies were calculated for each group in order to estimate the sexual maturity minimum size. Sexual maturity length was estimated according to the formula recommended by Udupa (1986). A Sigmoid curve was set manually to fully matured male and female adults by length class to plot data of the first maturity length. Length reached by $50 \%$ of matured individuals was considered the sexual maturity length.

\section{RESULTS}

\section{Water level fluctuations}

Maximum and minimum water levels in Manaus are greater than around Tefé. Dry period started earlier and lasted longer (August, November) in the area of Tefé during the period of study (Fig. 3).

\section{Measurement conversion}

In Table 2 we present equations describing the relationship of measurements between length and weight.

High values of $r^{2}$ show a good fit to the linear model, so, it's possible to predict dependent variable values from the independent variable.

\section{Sex ratio}

There weren't any significant differences between male and female numbers and so we accept the hypothesis that sex ratio is $1: 1$. There were significant differences between male and female standard length $\mathrm{t}=2.508(\mathrm{P}=0.013$, < $0.05) \mathrm{gl}=236$, female lengths being bigger than male's (Table 3).

\section{Weight/Length relationships}

Relationship between gutted weight (W) and standard length (SL) for tambaqui is described by the following equations:

$$
\begin{aligned}
& \mathrm{W} \text { females }=6.9 .10^{-5} . \mathrm{SL}^{2.8773} \\
& \mathrm{~W} \text { males }=0.00013 . \mathrm{SL}^{2.7715} \\
& \mathrm{~W} \text { undetermined }=3.6 .10^{-5} . \mathrm{SL}^{2.9978} \\
& \mathrm{~W} \text { total }=5.8 \cdot 10^{-5} . \mathrm{SL}^{2.904}
\end{aligned}
$$

The values $\mathrm{a}, \mathrm{b}$ and correlation coefficients for total specimens and by sexes, may be seen on Table 4 . The values were significantly different from $3(\mathrm{P}<0.001)$ for the total of specimens and for males indicating an alometric growth. 


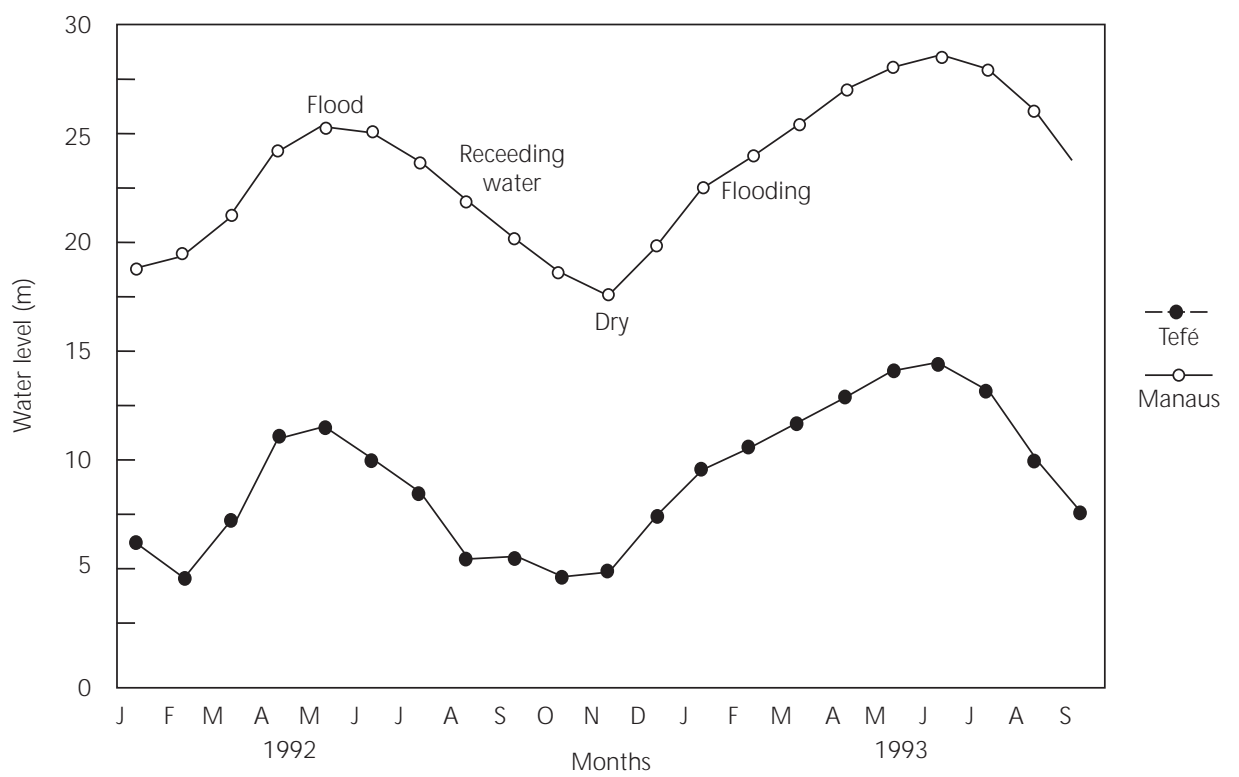

Fig. 3 - Water level fluctuations, during the study period in Manaus (Rio Negro) and Tefé (Rio Solimões). Data provided by Capitania dos Portos in Manaus (PORTOBRAS) and Mamirauá project in Tefé.

TABLE 2

Prediction equation data of lengths and weights $C$. macropomum $\mathbf{n}=$ number of specimens, ax $=$ range of independent variable, $\mathrm{Tl}=$ total length, $\mathrm{St}=$ Standard length, $\mathrm{Fl}=$ Fork length, $\mathrm{Pt}=$ Total weight, $\mathrm{Wg}=$ Gutted weight, $\mathbf{r}^{2}=$ coefficient of determination.

\begin{tabular}{|l|l|l|l|}
\hline $\begin{array}{l}\text { Equation } \\
\mathbf{y}=\mathbf{a}+\mathbf{b x}\end{array}$ & $\mathbf{A x}$ & $\mathbf{r}^{\mathbf{2}}$ & $\mathbf{n}$ \\
\hline $\mathrm{Tl}=4.405+1.22 \mathrm{Sl}$ & $11-605(\mathrm{~mm})$ & 0.9962 & 99 \\
\hline $\mathrm{Sl}=-3.152+0.816 \mathrm{Tl}$ & $74-720(\mathrm{~mm})$ & 0.9962 & 99 \\
\hline $\mathrm{Tl}=-6.188+1.109 \mathrm{Fl}$ & $13-740(\mathrm{~mm})$ & 0.9935 & 140 \\
\hline $\mathrm{Fl}=6.723+0.895 \mathrm{Tl}$ & $14-822(\mathrm{~mm})$ & 0.9935 & 140 \\
\hline $\mathrm{Sl}=-3.045+0.885 \mathrm{Fl}$ & $11-605(\mathrm{~mm})$ & 0.9944 & 155 \\
\hline $\mathrm{Fl}=4.353+1.124 \mathrm{Sl}$ & $13-685(\mathrm{~mm})$ & 0.9944 & 155 \\
\hline $\mathrm{Wt}=-49.207+1.125 \mathrm{Wg}$ & $1.04-24,000(\mathrm{~g})$ & 0.9969 & 440 \\
\hline $\mathrm{Wg}=56.207+0.886 \mathrm{Wt}$ & $1.18-28,500(\mathrm{~g})$ & 0.9969 & 440 \\
\hline
\end{tabular}

In females and undetermined sex specimens, the regression coefficient wasn't signifficantly different from 3 ( $\mathrm{P}>0.001)$ indicating an alometric growth in these specimens (Table 4). Fig. 4 describes weight/length relationship.

\section{Condition Index (Kn)}

During receding water and dry season, condition index values fluctuated from month to month. Significantly lower mean values were found in the months of August $(\mathrm{P}<0.05)$ and October $(\mathrm{P}<0.05)$ in the end of the receding water and dry season. During rising water (January-May) there was a gradual increase Kn mean values (Fig. 5).

\section{Feeding Index (FI)}

From July till December during the receding and dry season, FI mean values were significantly lower $(\mathrm{P}<0.05)$ indicating that during this period tambaqui feeds less. 
TABLE 3

Chi quadrado test results applied to frequency absolute values of females, and mean length $\left(\mathrm{C}_{\text {med }}\right)$ per standard length class of $C$. macropomum.

\begin{tabular}{|c|c|c|c|c|c|c|}
\hline $\begin{array}{c}\text { Standard } \\
\text { length classes }\end{array}$ & $\begin{array}{c}\mathbf{n} \\
\text { Males }\end{array}$ & $\begin{array}{c}\mathbf{n} \\
\text { Females }\end{array}$ & $\begin{array}{c}\mathbf{n} \\
\text { total }\end{array}$ & $\begin{array}{c}\text { qui } \\
\text { quad }\end{array}$ & $\begin{array}{c}\mathbf{C}_{\text {med }} \\
\text { males }\end{array}$ & $\begin{array}{c}\mathbf{C}_{\text {med }} \\
\text { females }\end{array}$ \\
\hline $300-349$ & 2 & 1 & 3 & - & 346.50 & 348.00 \\
\hline $350-399$ & 8 & 8 & 16 & 0 & 378.62 & 384.75 \\
\hline $400-449$ & 1 & 3 & 4 & - & 349.33 & 440.00 \\
\hline $450-499$ & 7 & 1 & 8 & - & 384.14 & 455.00 \\
\hline $500-549$ & 16 & 10 & 26 & 1.38 & 529.06 & 526.00 \\
\hline $550-599$ & 28 & 25 & 53 & 0.17 & 576.00 & 574.04 \\
\hline $600-649$ & 17 & 18 & 35 & 0.028 & 619.35 & 627.89 \\
\hline $650-699$ & 25 & 25 & 50 & 0 & 672.52 & 672.56 \\
\hline $700-749$ & 10 & 20 & 30 & 3.33 & 718.00 & 720.50 \\
\hline $750-799$ & 3 & 4 & 7 & - & 768.00 & 767.50 \\
\hline $800-849$ & 0 & 3 & 3 & - & - & 807.67 \\
\hline $850-899$ & 0 & 3 & 3 & - & - & 861.38 \\
\hline TOTAL & 117 & 121 & 238 & 0.076 & & \\
\hline
\end{tabular}

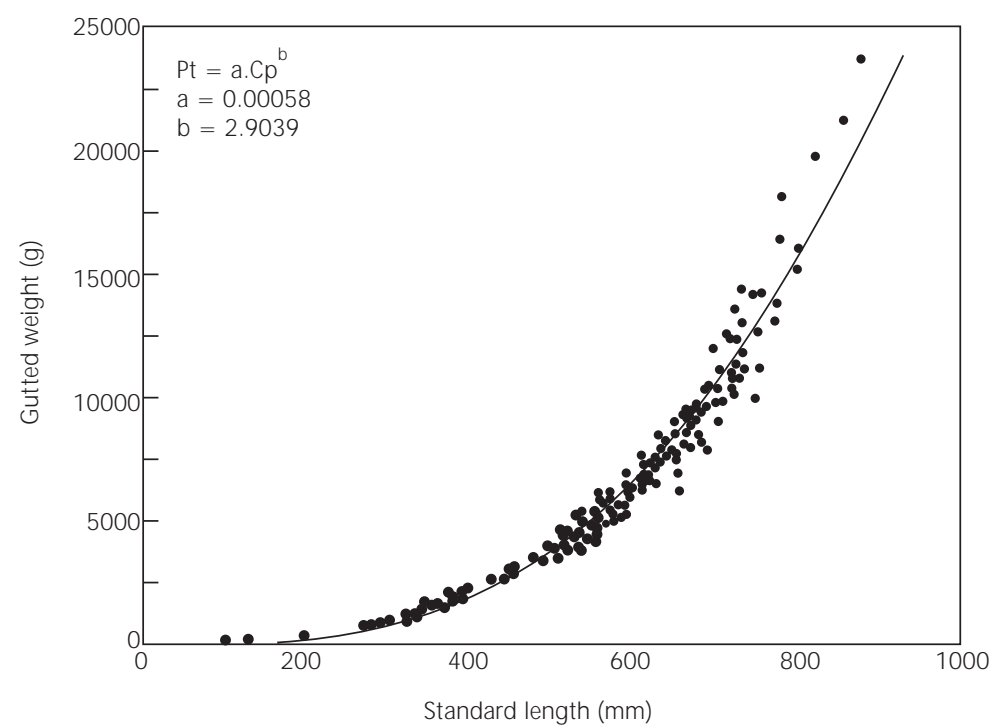

Fig. 4 - Dispersal plot and curve set on data for gutted weight and standard length of C. macropomum during the study period. 
TABLE IV

Data of regressions between gutted weight $\ln$ and standard weight $\ln$ of $C$. macropomum specimens throughout the study period. $\mathbf{N}=$ Number of specimens, ax = range of independent variable (standard length), $b=$ value of regression coefficient, $\ln a=$ value in $\ln$ of regression constant, $\mathbf{r}^{2}=$ determination coefficient.

\begin{tabular}{|l|l|l|l|l|l|l|l|}
\hline Sex & $\mathbf{a x}(\mathbf{m m})$ & $\mathbf{b}$ & $\mathbf{l n} \mathbf{a}$ & $\mathbf{r}^{\mathbf{2}}$ & $\mathbf{n}$ & $\mathbf{t}$ & $\mathbf{P}$ \\
\hline Females & $348-877$ & 2.8773 & -9.5872 & 0.9719 & 116 & 0.612 & $\mathrm{P}>0.001$ \\
\hline Males & $344-775$ & 2.7715 & -8.9492 & 0.9722 & 117 & 5.221 & $\mathrm{P}<0.001$ **** \\
\hline Nondetermined & $34-357$ & 2.9978 & -10.223 & 0.9936 & 192 & 1.648 & $\mathrm{P}>0.001$ \\
\hline Total & $34-877$ & 2.9036 & -9.7620 & 0.9976 & 425 & 14.072 & $\mathrm{P}<0.001$ **** \\
\hline
\end{tabular}

** b significantly different from 3

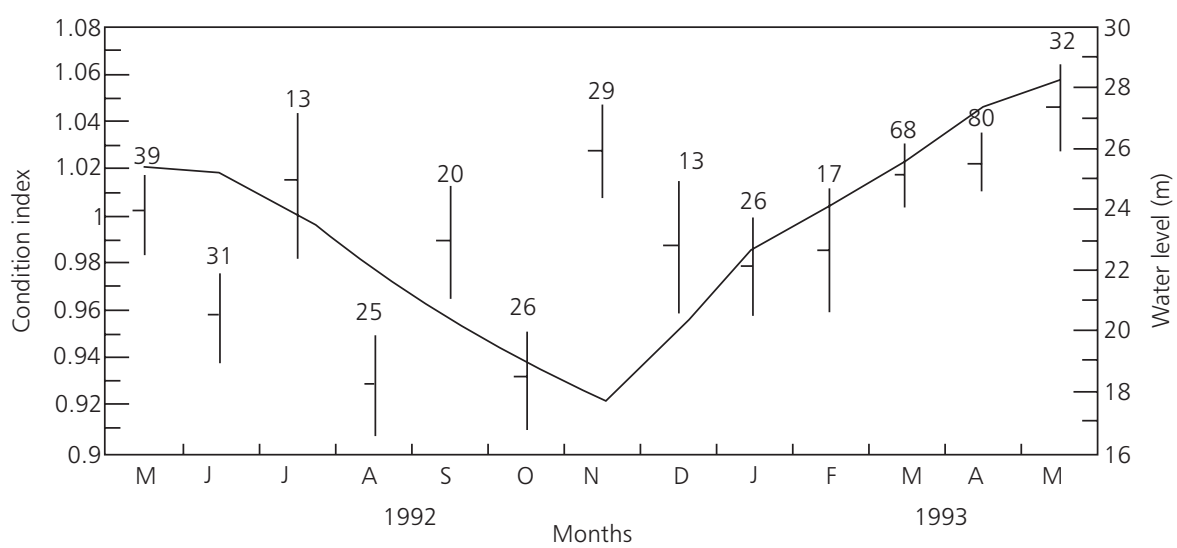

Fig. 5 - Condition index of C. macropomum and water level fluctuations. Mean values, confidence limits of $95 \%$ and size of sample.

From January till June during rising water and flooding FI values were higher indicating a more intensive feeding period (Fig. 6).

\section{Hepatosomatic Index (HSI)}

Low values of HSI were found from August to November and in December the mean value was significantly lower $(\mathrm{P}<0.05)$ in relation to the other months. In January HSI rose suddenly and from February on, the tendency of the values was to rise with an exception for the month of April when a significant drop was recorded $(\mathrm{P}<0.05)$ (Fig. 7).

\section{Cavitary fat accumulation}

Few cavitary fat deposits (grade 1) were found in tambaqui during rising and flooding period. During receding and dry periods, moderate cavitary fat deposits partially cover the bowels (grade 2). Fish with abundant fat deposits covering totally the bowels and abdominal cavity only occur during low water period (Fig. 8).

Most specimens with little cavitary fat accumulation had lengths smaller than $600 \mathrm{~mm}$ and abundant fat deposits in the abdominal cavity were noted mainly on fish in standard length classes longer than $550 \mathrm{~mm}$ (Fig. 9).

\section{Gonadosomatic Index (GSI)}

There were significant differences between gonadosomatic index monthly mean values $(\mathrm{P}<$ $0.001)$. There were significant diferences $(\mathrm{P}<0.05)$ between September/October, and January/ February monthly means. These results imply the specie reproductive period is from September till February, spawning occurring between the months of September/October and January/February 
(Fig. 10). Maturating gonads higher frequencies (stage II) occurred in August, October and December. Mature gonads (stage III) were more frequent between September and November. From November to February there occurred the highest frequencies of emptied gonads (stages IV and V) (Fig. 11). These results confirm that the species reproductive period extends from September to February.

As September and December samples were collected closer to Tefé, we found it convenient to interpret this result considering the hydrological cycle in Tefé. By analysing water level variation between months when there was a significant drop in the GSI values which indicates spawning, we noted that it coincided with to "repiquete" (Fig. 12).

As January and February samples were collected in areas near Manaus, these were interpreted according to the water level fluctuations in Manaus (Rio Negro). In spite of not having been as evident, there also was a repiquete in this area during this period. Unfortunately we couldn't count with data Rio Solimões water level near Manaus, where "repiquetes" are probably more prominent.

\section{Sexual maturity length}

Sexual maturity length of tambaqui was 60.69 $\mathrm{cm}$. Length in which $50 \%$ of adults are in the gonads phase of maturity $\left(\mathrm{L}_{\mathrm{m}} 50\right)$, was in the 60 $\mathrm{cm}$ length class, which agrees with results found by applying Udupa's formula (1986). Standard length in which $100 \%$ of the adults of population were adult $\left(\mathrm{L}_{\mathrm{m}} 100\right)$, was of $76 \mathrm{~cm}$ (Fig. 13).

\section{DISCUSSION}

Water level oscillations in Central Amazonas, which may reach up to $15 \mathrm{~m}$ depending upon their geographical area, help in the physico-chemical environmental changes development. These changes co-operated in the evolution of biological mechanisms, which enable for a high biological productivity and nutrients recycling (Junk \& Welcome, 1990; Junk et al., 1989; Goulding, 1980).

Along their evolution process fish adapt themselves to environmental seasonality, by developing morphological, anatomical, physiological and behavioural adaptations (Braun \& Junk, 1982; Saint-Paul \& Soares, 1988; Junk et al., 1997) for the proper exploitation of all the available different habitats.

Thus, performance of all essential functions during the life cycle, such as, growth, reproduction and feeding are closely related to variations existent within the system (Junk \& Welcome, 1990). Tambaqui C. macropomum is a successful species within floodplain environments, being a very important resource for the sustainability of a major part of the local economy.

According to our results, tambaqui is found in nature in a sex ratio of $1: 1$, which agrees with results found for this species by Isaac et al. (in press). The bigger lengths reached by females may be due either to a growth differential in which females reach larger sizes or to fishing gear's selection. Villacorta Correa (1997), found that tambaqui grow bigger than males after sexual maturity.

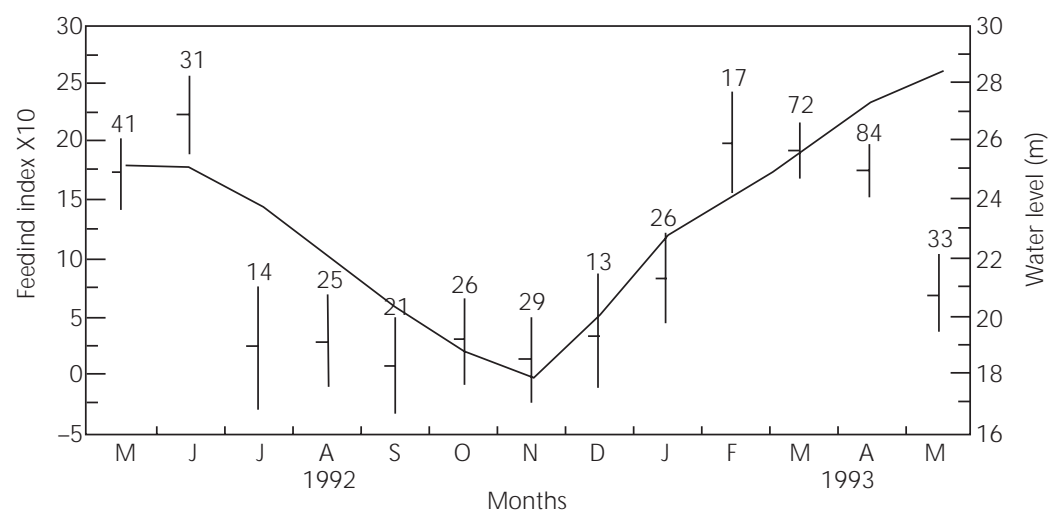

Fig. 6 - Feeding index of C. macropomum and water level fluctuations. Mean values. Confidence limits of $95 \%$ and size of sample. 


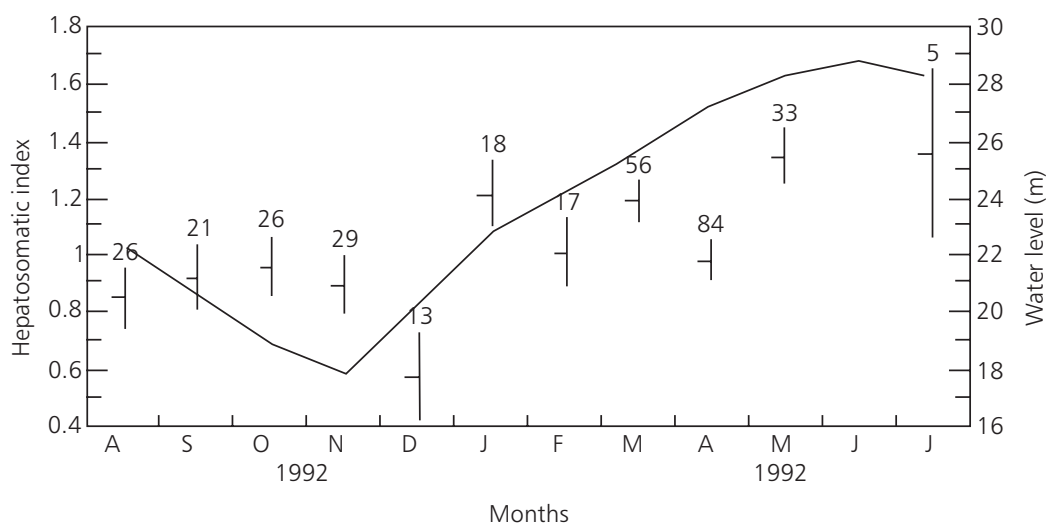

Fig. 7 - Hepatosomatic index of C. macropomum. Mean values. Confidence limits of $95 \%$ and size of sample.

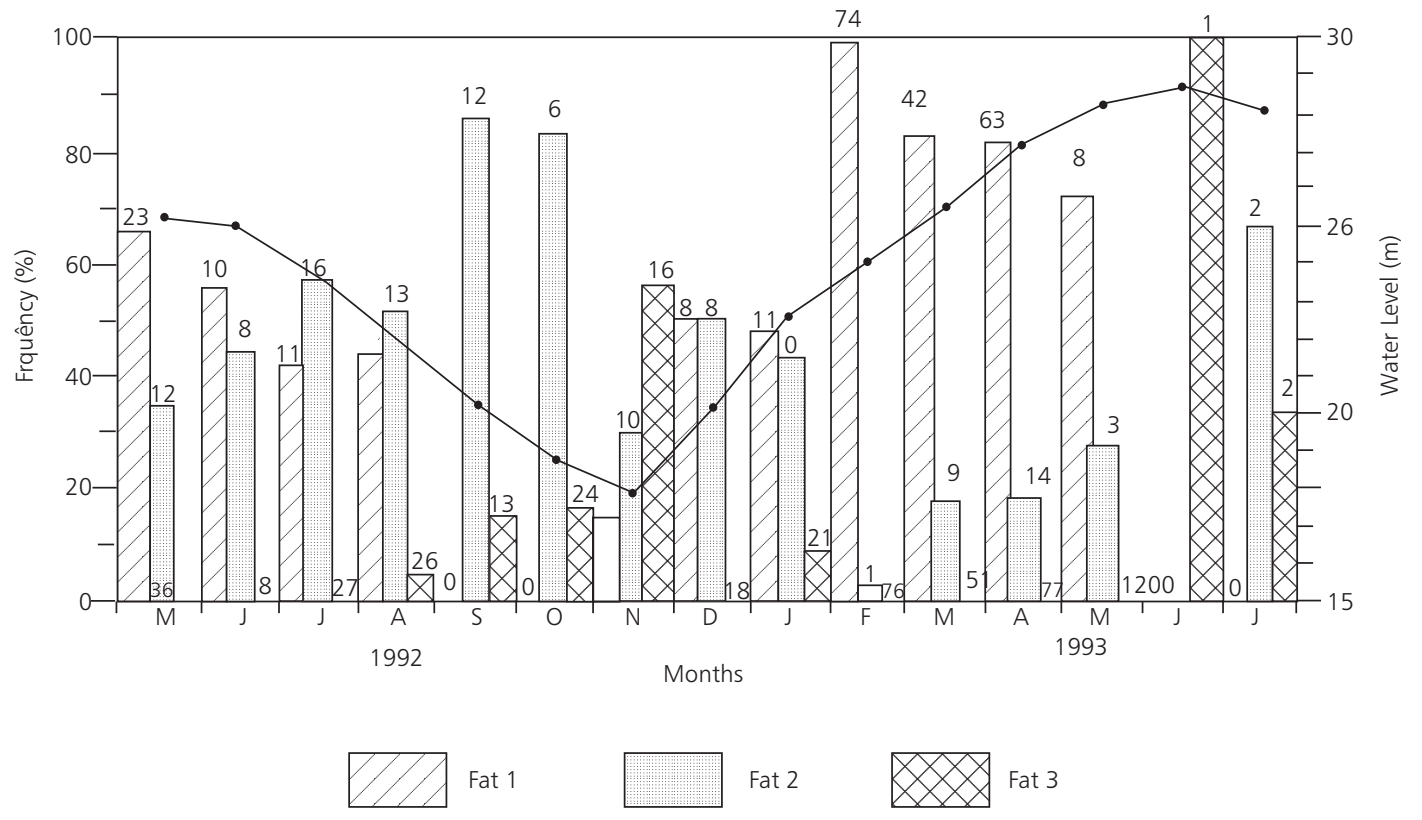

Fig. 8 - Cavitary fat monthly occurrence frequency of C. macropomum and water level fluctuations. 

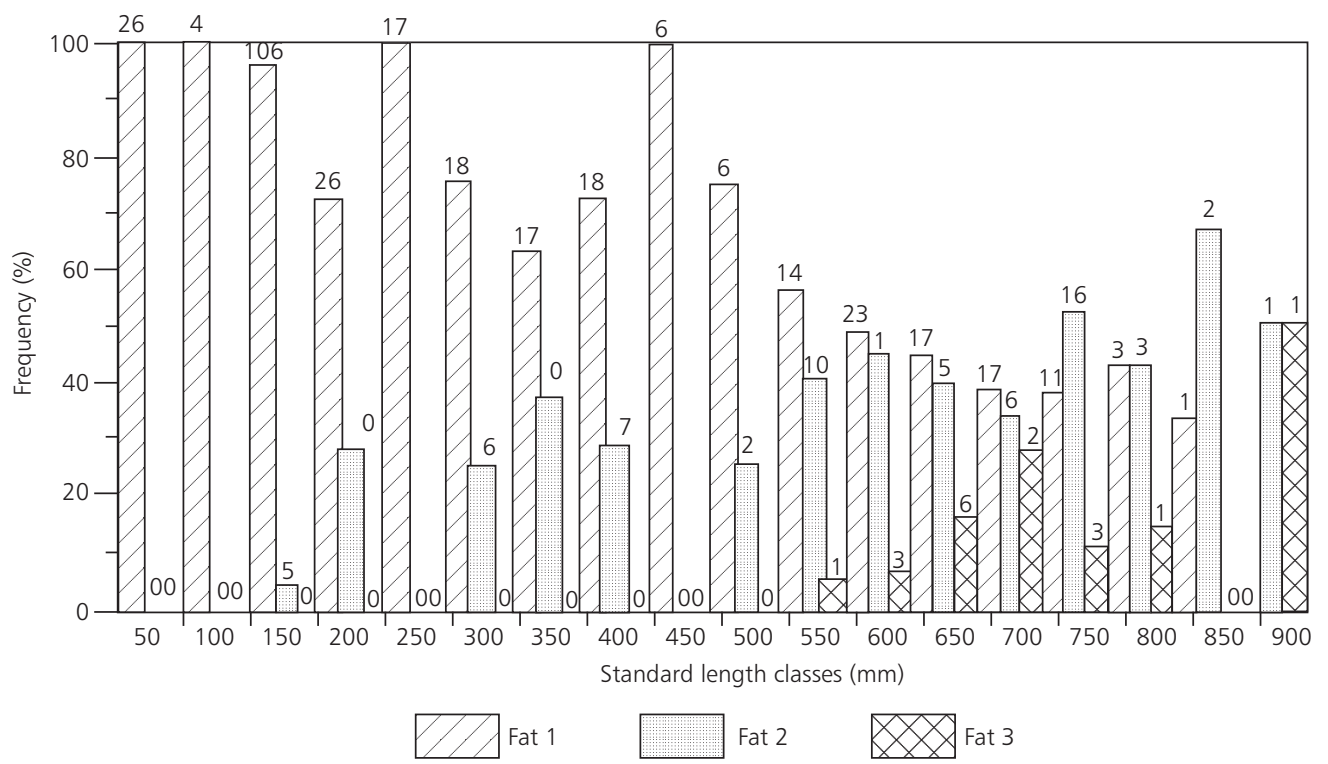

Fig. 9 - Cavitary fat occurrence frequency of $C$. macropomum by standard length class. Numbers in the plot represent the size of sample.

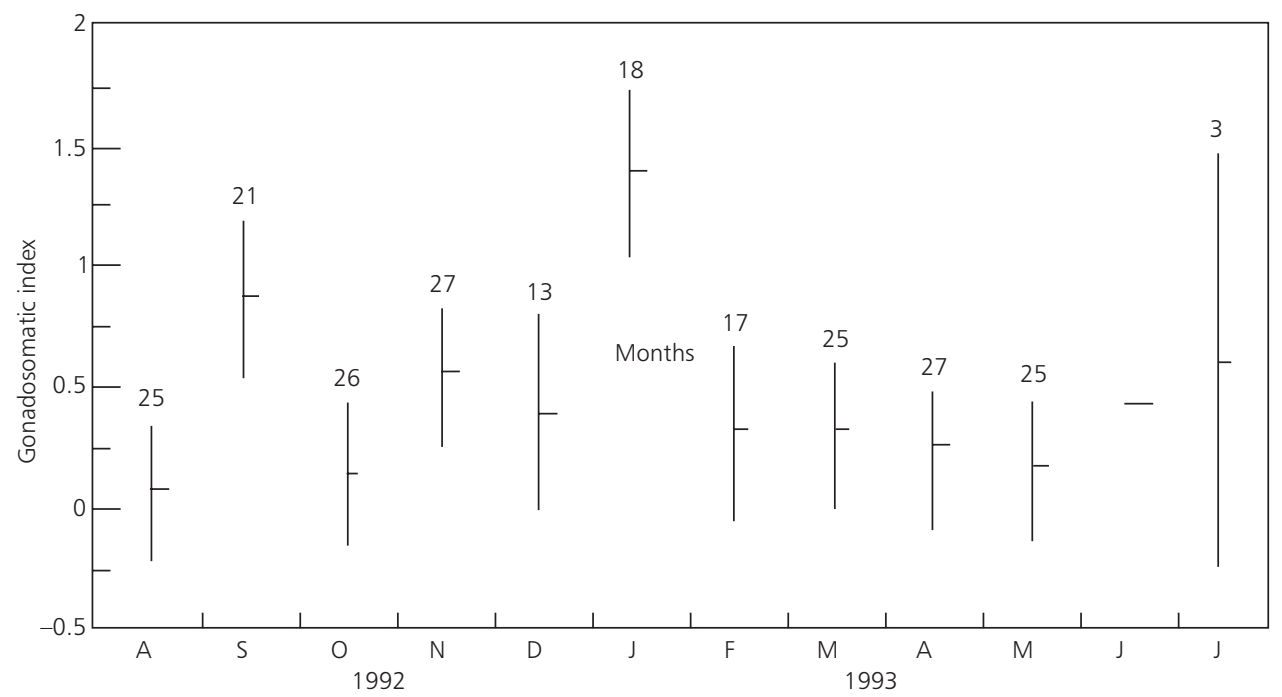

Fig. 10 - Gonadosomatic index of C. macropomum and water level fluctuations. Mean values with $95 \%$ of confidence intervals. 


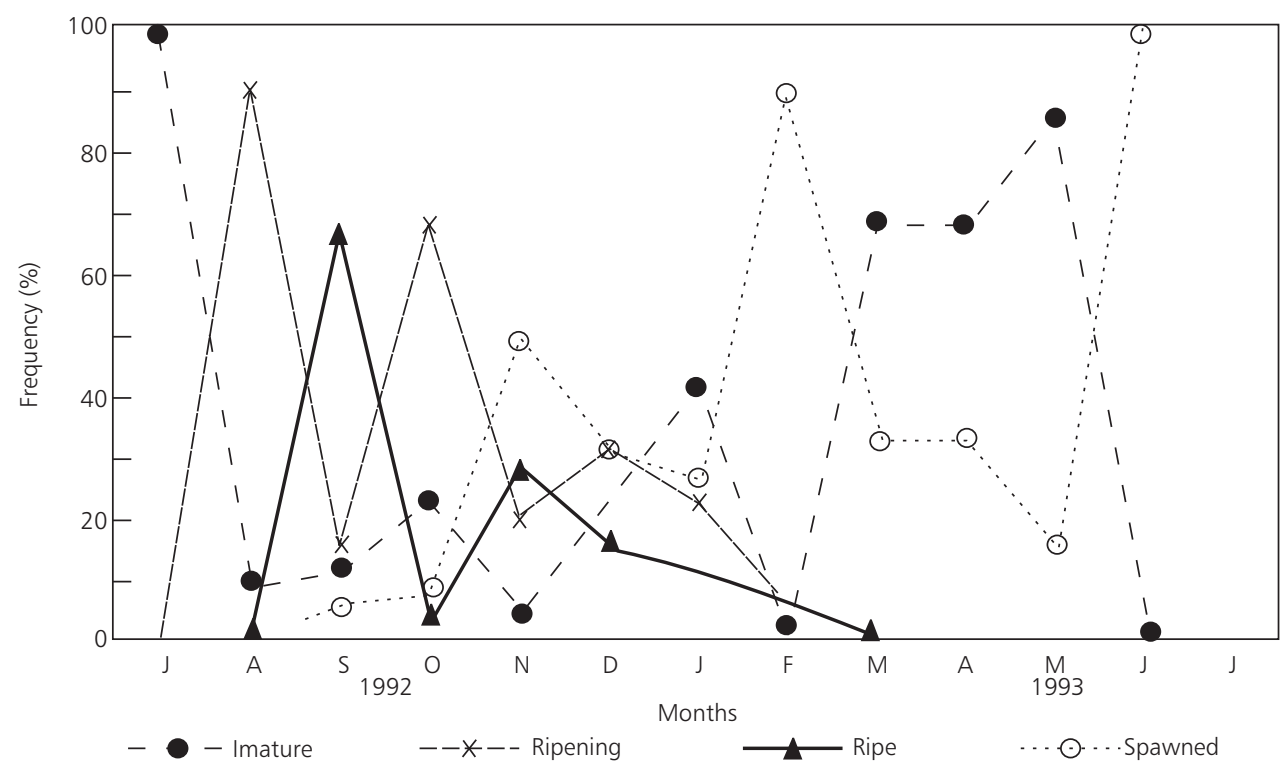

Fig. 11 - Monthly mean values of sexual maturity stages of C. macropomum.

As quoted by Isaac et al. (in press), female's larger growth may be a strategy for the increase of population fecundity.

In the formula which describe weight/length relationship, $b$ is interpreted as an allometric coefficient. Generally when b is less than 3, it means that fish are less round, $b$ values of more than 3 it means fish are rounder as fish length increases, and when $b$ is equal 3 growth is isometric, which means, fish shape doesn't change as fish grows (Anderson \& Neuman, 1997). So, value of $b$ may be variable in fish from different locals, different sexes and length classes, being able to represent taxonomical differences and to reflect differenciated growth phases in a species development (Le Cren, 1951).

In tambaqui, $b$ value of the weight/length relationships for all specimens was significantly different from 3, which represents an alometric growth. This result is similar to the one found by Costa (1998) and different from those found by Petrere (1983) and Isaac \& Rufino (1996).

Differences may be due either to the fact that in this work, were included smaller fish (from 34 $\mathrm{mm}$ ) and considered all lengths classes, or due to the existence of alometry in growth according to sex.
Analysis of the fishes weight/length relationship expressed as a condition index $(\mathrm{Kn})$, is interpreted as an condition fatness, general well being, gonadal development etc. (Le Cren, 1951). Low values of the condition index found in tambaqui during receding and dry period may be ascribed to: reproductive migrations, gonads development, spawning and also to scarce feeding throughout this period. These factors may have brought a physiological stress during receding water and dry period. The limited migratory movements and abundant feeding during the rising water and flooding period may be contributed for the improvement of the fish's physiological status within this seasonal period which was reflected in the higher values of the condition index.

Since tambaqui is a species whose feeding habit is mostly frugivorous (Goulding, 1980; Goulding \& Carvalho, 1982; Moreira, 1997), the feeding index high values found during rising and flooding, may be related to larger amounts of fruits and seeds available during these periods as consequences of forest flooding.

Built up stores either in the form of cavitary fat or of glicogen in the liver, seem to balance the scarce feeding phase during the dry period or during tambaqui's reproductive migrations. 


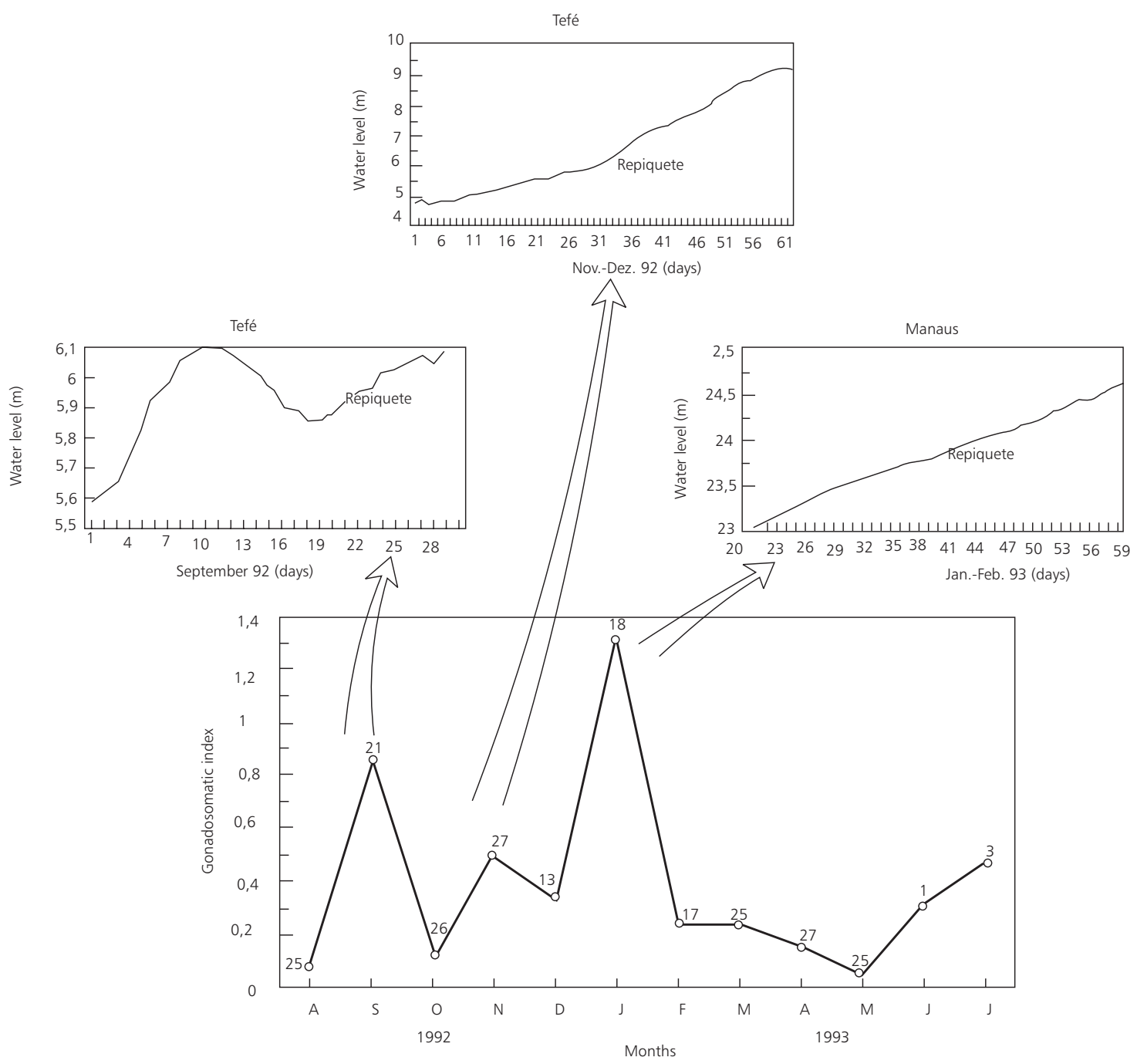

Fig. 12 - Monthly gonadosomatic index of C. macropomum and water level fluctuations in Tefé and Manaus during the study period.

Hepatosomatic index low values were found during receding and dry period. This result is similar to the one found by Saint-Paul (1984) for young tambaqui specimens collected from Lago Manaquiri.

The low values found may be due to the usage at stores accumulated in the liver for supplying energetic requirements during the time of scarce food items, sexual products elaboration and spawning activity, which occur throughout the flooding and early rising respectively.

During receding and rising water periods, most specimens present little accumulation of fat in the abdominal cavity. These results are different from the ones found by Junk (1985), and Castelo et al. (1980), who found larger stores of fat in the high water periods.

This dissent may be on account of that in this work adult specimens weren't collected during rising and flooding, since it was proved the high fat stores were only found in specimens above 550 mm standard length. Adult specimens weren't captured in flooded areas, probably due to the fact that the greatest capture is accomplished in floodplain lakes were young population is prevailing. 
Winemiller (1989), identified three types of reproductive strategies for floodplain fish in Venezuela: seasonal, in equilibrium and opportunistic. According to this author, species with seasonal reproductivity have adaptations to the changes in the level of the river and to rainfall annual patterns. According to these strategies, Isaac et al. (in press) classified tambaqui as a species with a seasonal reproductive strategy, with fully synchronic spawning, adapted to the hydrological and rainfall pattern. According to these authors, tambaqui's spawning times occurs in the beginning of the flooding (December till March). In a study regarding the tambaqui's reproductive biology, Vieira (1996), found that this species has total spawning and synchronic ovocitary development in two groups, those of the reserve stores and the other ones which are eliminated in the spawning.

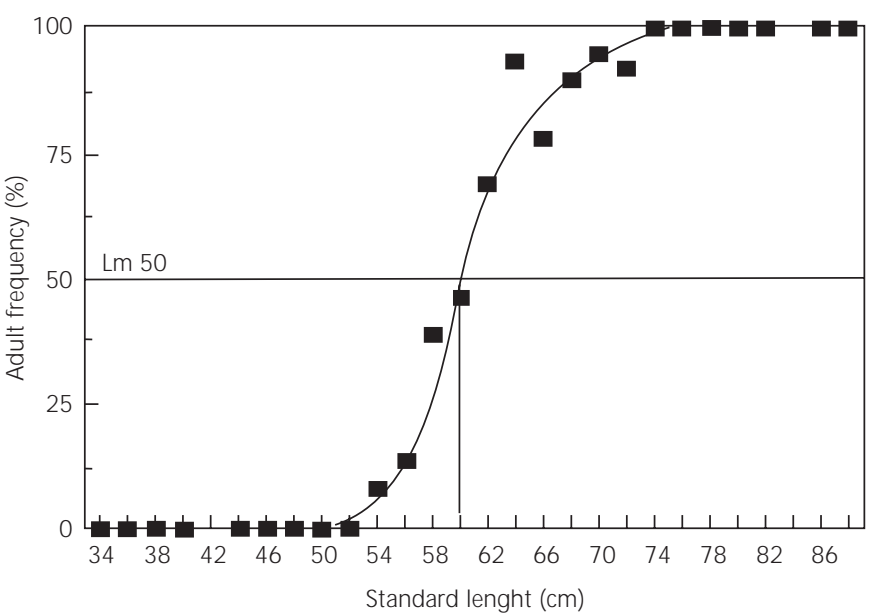

Fig. 13 - Distribution of accumulated relative frequency of C. macropomum adults by standard length classes.

The gonadosomatic index analysis found in this work and the monthly variation of the sexual maturity stages, disclosed that the reproductive period of tambaqui within the study area es from September till February, there being successive drop in the GSI values within these months.

Sudden drop in the GSI might reflect, either a period of reproduction divided into fractions, or geographical differences in the spawning. Since specimens come from different locallities in the basin (Area of Tefé and area of Manaus) the latter hypothesis may be more probably implying that the population spawning is synchronical with the water level fluctuations. According to folk knowledge, "repiquetes" are ecological events of great importance that act as estimulation of a fish's spawning. Our data point out that tambaqui's spawning peaks coincide with 'repiquetes' this may be a strategy to guarantee the supply of food for small fish in the recently flooded areas and to assure for the preservation of species.
As tambaqui's spawning occurs from September till February, there are geographical differences according to the hydrological pattern. In the areas of Tefé it starts in between September/October and in the area of Manaus later in between November and February. Isaac et al. (in press) found that spawning period in the lower Solimões is from December to March. Therefore either policies regulating "defeso" should be longer duration considering water level oscillations in the basin as a whole or policies should differ according to geographical area.

Goulding \& Carvalho (1982), state as possible spawning areas the grassy levees which are flooded by the rising of the waters and Costa $e t$ al. (1999) suggested that spawning is in the areas of "pauzadas" (deep marginal river areas. They usually appear on the main river channel and accumulate branches, shrubs and trees dragged and deposited due the centrifugal action of water current) which exist along the white water rivers. 
Eggs and larva are carried downstream by the water current and larva enter the floodplain areas adjoining the white water main river. In this places fish are bred and spend their early life stages.

In this study, fishes between 13 and $150 \mathrm{~mm}$ in standard length were exclusively found in the banking grasses (floating and rooted) located in the banks of white water rivers, in resacas (shallow water and floodplain lakes near the main channel of white water rivers. These factors contribute to suggest that this species' spawning occurs within white water rivers and that fish remain in the bank areas close to the main white water river in the early phases of its life cycle.

According to Goulding \& Carvalho (1982), young tambaqui remains from 4 to 7 months within the flooded areas and as the water recede it moves to the floodplain lakes which will remain even after the draining of the forest. Costa et al (1999) in a marking and recapturing study of tambaqui in Mamirauá Ecological Station (Tefé), report that this species remains within the floodplain lakes, until reaching close to $60 \mathrm{~cm}$ of fork length and five years of age, when they leave these areas and undertake their up river migration in the mean river adjoining the adult stock.

Results of this study point out that $C$. macropomum reaches sexual maturity with 60.69 $\mathrm{cm}$ standard length. This results agrees with those obtained by Loubens \& Aquim (1986) for fish in Orinoco River (Venezuela) and Pinheiro (1986) who worked with fish in the area of Tefé. Goulding \& Carvalho (1982) estimated tambaqui's first maturity at $560 \mathrm{~mm}$ standard length. Therefore, with this work we can state that the trigger for the fish to leave the floodplain lakes is the gonads maturity which occur during the upriver migration.

Analysis of the different structural indexes studied in this work, show that the life strategy of tambaqui is adapted to the water level fluctuations and exploits the available habitats in na efficient manner. Therefore the preservation of the flooding areas should be an strategy incorporated to the species management projects, regardless of any other policy concerning the capture in order to assure its preservation and sustainability.

Acknowledgments - This paper is resulted from the cooperation between the Max-Plack Institute für Limnologie Arbeitegrupe für Tropenskologie, Plon and the Instituto Nacional de Pesquisas da Amazônia (INPA) under the Governmental agreement on co-operation in field of
Scientific Research and Technological Development between German Ministry for Science and Technology (BMFT), Project number 03390366 A, The Neotropical Floodplain Forest: Relation between Fish and Environment). The Conselho Nacional de Pesquisa e Tecnologia $(\mathrm{CNPq})$ and the Instituto Brasileiro de Meio Ambiente e Recursos Naturais Renováveis (IBAMA).

\section{REFERENCES}

ANDERSON, R. O. \& S. J. NEUMANN R. M., 1996, Length, weight and associated structural indices, pp. 283299. In: S. K. Murphy B. R. \& D. W. Willis (eds.), Fisheries Techniques. Second edition. American Fisheries Society, 732p.

BRAUM, E. \& JUNK, W. J., 1982, Morphological adaptation of two amazonian characoids (Pisces) for surviving in oxygen deficient waters. Int. Rev. Hydrobiol., 67: 869-886.

CASTElo, F. P., AMAYA, D. R. \& STRONG, F. C., 1980, Aproveitamento e características da gordura cavitária do tambaqui Colossoma macropomum CUVIER, 1818. Acta Amazônica, 10(3): 557-576.

COSTA, L. R., BARTHEM, R. \& VILLACORTA-CORREA, M. A, 1999, Manejo da pesca do tambaqui nos lagos de várzea da Estação Ecológica Mamirauá. In: H. L. Queiroz \& W. G. R. Crampton (eds.), Estratégias para manejo de recursos pesqueiros em Mamirauá. Sociedade Civil Mamirauá, MCT - CNPq, 196p.

COSTA, L. R., 1998, Subsídios ao manejo do tambaqui (Colossoma macropomum, Cuvier, 1818) na várzea do médio Solimões: Pesca, dinâmica de população, estimativa de densidade e dispersão. Dissertação de Mestrado, INPA/UFAM, Manaus, 76p.

GOULDING, M., 1980, The fishes and the forest. Explorations in amazonian natural history. University of California Press, Berkeley, 280p.

GOULDING, M., 1981, Man and fisheries on an Amazon frontier. The Hague: Dr. W. Junk Publications, 137p.

GOULDING, M. \& CARVALHO, M. L., 1982, Life history and management of the tambaqui (Colossoma macropomum, Characidae): An important amazonian food fish. Rev. Brasil. Biol., 1(2): 107-133.

HONDA, E. M. S., 1974, Contribuição ao conhecimento da biologia de peixes do Amazonas II. Alimentação do tambaqui, Colossoma bidens (Psix). Acta Amazônica, 4: 47-53.

ISAACC, V. J. \& RUFFINO, M. L., 1996, Population dynamics of tambaqui Colossoma macropomum. Cuvier, in the lower Amazon Brazil. Fisheries Management and Ecology, 3: 315-333.

ISAAC, V. J., ROCHA, V. L. C. \& MOTA, S. Q. C., no prelo, Ciclo reprodutivo de algumas espécies de peixes comerciais do médio Amazonas. IBAMA. Coleção Meio Ambiente, Série Estudos de Pesca, 35p.

JUNK, W. J., 1985, Temporary fat storage, an adaptation of some fish species to the water level fluctuations and related environmental changes of the Amazon River. Amazoniana, 9(3): 315-351. 
JUNK, W. J., BAYLEY, P. B. \& SPARKS, R. E., 1989, The flood pulse concept in the river floodplain systems. In: D. P. Dodge (ed.), Proceedings of the International Large River Symposium. Can. Spec. Pub. Fish. Aquatic Sciences, 106: 110-127.

JUNK, W. J. \& WELCOME, R. L., 1990, Floodplains. p. 491-524. In: B. C. Patten (ed.), Wetlands and shallow continental water bodies. SPB Academic Publishing by The Hague, The Netherlands.

JUNK, W. J., SOARES M. G. \& SAINT-PAUL, U., 1997, The Central-Amazonian Floodplain: Ecology of a pulsing System. Ecological studies. Vol. 126. Springer Verlag, Berlin, pp. 385-408.

LE CREN, E. D., 1951, The length- weight relationship and cycle of gonad weight and condition in the perch Perca fluviatilis. J. Anim. Ecol., 20(2): 201-219.

LOUBENS, G. \& AQUIM, J. L., 1986, Sexualidad y reprodución de los principales peces de la cuenca del río Mamore, Bení e Bolivia. Informe Científico, 5. Convénio ORSTOM-UTB-CORDEBENI, 45p.

MERONA, B. de \& BITTENCOURT, M. M., 1988, A pesca na Amazônia através da análise dos desembarques no mercado de Manaus (AM, Brasil). Mem. Soc. Cien. Nat. La Salle, 48: 433-453.

MOREIRA, J. A. S. da, 1997, Nutrientes, energia $e$ digestibilidade aparente de frutos e sementes consumidos pelo tambaquí (Colossoma macropomum Cuvier, 1818) nas florestas inundáveis da Amazônia Central. Tese de doutorado, PPG INPA/FUA, Manaus, AM, 148p.

NIKOLSKY, G. V., 1963, The ecology of fishes. Academic Press, London, 352p.

PAULY, D., 1984, Fish population dynamics in tropical waters: A manual for use with programmable calculators. ICLARM. living Aquatic Resources Management. Manila, Philippines, 325p.

PETRERE, Jr. M., 1983, Yield per recruit of the tambaqui, Colossoma macropomum Cuvier, in the Amazonas State, Brazil. J. Fish Biol., 22: 133-144.

PINHEIRO, A. R. C., 1986, Biologia pesqueira do tambaqui, Colossoma macropomum (Cuvier, 1818), capturado no município de Tefé, Estado do Amazonas. Dissertação, DEPCCA, Universidade Federal do Ceará, Fortaleza, $21 \mathrm{p}$.

RUFFINO, M. L. \& ISAAC, N. J., in print, Life cycle and biological parameters of several Brazilian Amazon fish species.
SAINT-PAUL, U., 1984, Investigations on the seasonal changes in the chemical composition of liver and condition from a neotropical Characoid fish Colossoma macropomum (Serrasalmidae). Amazoniana, 9(1): 147158.

SAINT-PAUL, U., 1986, Potential for aquaculture of South American freshwater fishes: a review. Aquaculture, 54: 205-240.

SAINT-PAUL, U., 1990, Aquaculture in Latin America. Bibliography. European Aquaculture Society. Special Publication, 13, 434p.

SAINT-PAUL, U. \& SOARES, M. G., 1988, Ecomorphological adaptation to oxygen deficiency in amazon floodplain by Serrasalmid fish of the genus Mylossoma. J. of Fish Biol., 32: 231-236.

SAYER, M. D. J., GIBSON, R. N. \& ATKINSON, R. J. B., 1995, Growth, diet and condition of goldsinny on the west coast of Scotland. J. Fish. Biol., 46: 317-340.

SOKAL, R. R. \& ROHLF, F. J., 1995, Biometry. The principles and practice of statistics in biological research. Third edition. W. H. Freeman and Co, New York, 887p.

UDUPA, K. S., 1986, Statistical method of estimating the size at first maturity in fishes. Fish Byte, August, 1986, pp. 8-10.

VAZZOLER, A. E. A. de M., 1996, Biologia e Reprodução de peixes Teleósteos: teoria e prática, Ed. EDUEN, São Paulo, 169p.

VILLACORTA-CORREA, M. A., 1997, Estudo de idade e crescimento do tambaqui Colossoma macropomum (CHARACIFORMES:CHARACIDAE) no Amazonas Central, pela análise de marcas sazonais nas estruturas mineralizadas e microestruturas nos otólitos. Tese de Doutorado, INPA/FUA, Manaus (AM), 215p.

VIEIRA, E. F., 1996, Biologia reprodutiva do tambaqui (Colossoma macropomum Cuvier, 18181, Teleostei, Serrasalmidae) no médio Amazonas. Trabalho de conclusão de curso, Licenciatura Plena em Ciências Biológicas. Faculdade Integradas do Tapajós, Santarém, PA, 24p.

WINEMILLER, K. O., 1989, Patters of variation in life history among South American fishes in seasonal environments. Oecologia, 81: 225-241. 